\title{
An eddy-stimulated hotspot for fixed nitrogen-loss from the Peru oxygen minimum zone
}

\author{
M. A. Altabet ${ }^{1}$, E. Ryabenko ${ }^{2}$, L. Stramma ${ }^{2}$, D. W. R. Wallace ${ }^{3}$, M. Frank ${ }^{2}$, P. Grasse ${ }^{2}$, and G. Lavik \\ ${ }^{1}$ School for Marine Science and Technology, University of Massachusetts Dartmouth, 706 Rodney French Blvd, \\ New Bedford, MA 02744-1221, USA \\ ${ }^{2}$ GEOMAR Helmholtz Centre for Ocean Research Kiel, Düsternbrooker Weg 20, 24105 Kiel, Germany \\ ${ }^{3}$ Halifax Marine Research Institute, Dalhousie University, 1355 Oxford Street, P.O. Box 15000, Halifax, \\ Nova Scotia B3H 4R2, Canada \\ ${ }^{4}$ Max Planck Institute for Marine Microbiology, Celsiusstr. 1, 28359 Bremen, Germany
}

Correspondence to: M. A. Altabet (maltabet@umassd.edu)

Received: 30 May 2012 - Published in Biogeosciences Discuss.: 2 July 2012

Revised: 25 October 2012 - Accepted: 1 November 2012 - Published: 3 December 2012

\begin{abstract}
Fixed nitrogen (N) loss to biogenic $\mathrm{N}_{2}$ in intense oceanic $\mathrm{O}_{2}$ minimum zones (OMZ) accounts for a large fraction of the global $\mathrm{N}$ sink and is an essential control on the ocean's N-budget. However, major uncertainties exist regarding microbial pathways as well as net impact on the magnitude of N-loss and the ocean's overall N-budget. Here we report the discovery of a N-loss hotspot in the Peru OMZ associated with a coastally trapped mesoscale eddy that is marked by an extreme $\mathrm{N}$-deficit matched by biogenic $\mathrm{N}_{2}$ production, high $\mathrm{NO}_{2}^{-}$levels, and the highest isotope enrichments observed so far in OMZ's for the residual $\mathrm{NO}_{3}^{-}$. High sea surface chlorophyll in seaward flowing streamers provides evidence for offshore eddy transport of highly productive, inshore water. Resulting pulses in the downward flux of particles likely stimulated heterotrophic dissimilatory $\mathrm{NO}_{3}^{-}$reduction and subsequent production of biogenic $\mathrm{N}_{2}$ within the $\mathrm{OMZ}$. A shallower biogenic $\mathrm{N}_{2}$ maximum within the oxycline is likely a feature advected by the eddy streamer from the shelf. Eddy-associated temporal-spatial heterogeneity of $\mathrm{N}$-loss, mediated by a local succession of microbial processes, may explain inconsistencies observed among prior studies. Similar transient enhancements of N-loss likely occur within all other major OMZ's exerting a major influence on global ocean $\mathrm{N}$ and $\mathrm{N}$ isotope budgets.
\end{abstract}

\section{Introduction}

Extensive oxygen minimum zones (OMZ's, also known as $\mathrm{O}_{2}$ deficient zones - ODZ's) are found at intermediate depths in the Arabian Sea, off western Mexico, and off Peru and northern Chile. They arise regionally from poor ventilation of source waters and high downward fluxes of organic matter $(\mathrm{OM})$ supporting subsurface respiration. In these regions, the lack of $\mathrm{O}_{2}$ requires microbial heterotrophy to rely on oxidants other than $\mathrm{O}_{2}$ and include those that result in the biogenic production of $\mathrm{N}_{2}$ gas from chemically combined forms of $\mathrm{N}$. These processes also occur in anoxic marine sediments and in sum, account for almost the entire N-loss from the oceans (Codispoti, 2007; Gruber, 2008) and thereby are essential terms in the ocean's N-budget. The balance with $\mathrm{N}$ sources (from biologically mediated $\mathrm{N}_{2}$ fixation, rivers and the atmosphere) controls the oceanic fixed-N inventory (primarily as $\mathrm{NO}_{3}^{-}$) which, being an essential nutrient, is a major control on marine productivity. The overall magnitude of $\mathrm{N}$ loss from OMZ's is under debate and is a key determinant of whether the ocean's inventory of fixed- $\mathrm{N}$ is currently in steady-state or declining (Codispoti, 2007). Recent decadalscale expansion of OMZ's, a possible consequence of global warming (Stramma et al., 2008, 2009), suggests that oceanic $\mathrm{N}$-loss could be increasing, underscoring the need to understand the present state of the ocean's N-budget and the processes that control it. 
A number of interlinking microbial pathways contribute to N-loss in OMZ's and control the corresponding production of biogenic $\mathrm{N}_{2}$. Whereas heterotrophic denitrification (HDN; $\mathrm{NO}_{3}^{-} \rightarrow \mathrm{N}_{2}$ via $\mathrm{NO}_{2}^{-}$) was canonically viewed as dominant, important roles are now ascribed to the chemosynthetic anammox process (ANM; $\mathrm{NO}_{2}^{-}+\mathrm{NH}_{4}^{+} \rightarrow \mathrm{N}_{2}$; Kuypers et al., 2003) as well as dissimilatory nitrate reduction to ammonia (DNRA; $\mathrm{NO}_{3}^{-} \rightarrow \mathrm{NH}_{4}^{+}$via $\mathrm{NO}_{2}^{-}$; Lam et al., 2009). Recent studies disagree as to whether HDN or ANM is the dominant process for producing biogenic $\mathrm{N}_{2}$ (Ward et al., 2009; Bulow et al., 2010; Hamersley et al., 2007) and it remains unclear if these differences are the result of regional contrasts, time-space heterogeneity, or methodology (Voss and Montoya, 2009). Coupling these pathways can result in variable stoichiometry between $\mathrm{NO}_{3}^{-}$removal and $\mathrm{N}_{2}$ production provided there is an allochthonous supply of $\mathrm{NH}_{4}^{+}$. However, recent comparison between $\mathrm{NO}_{3}^{-}$deficits and biogenic $\mathrm{N}_{2}$ in several OMZ's are consistent with traditional stoichiometries (e.g. Chang et al., 2010), providing no evidence for allochthonous ammonium supporting the N-loss processes in the open ocean OMZ's. These microbial processes do vary in their environmental sensitivities, such as threshold $\mathrm{O}_{2}$ concentration (Kalvelage et al., 2011), so that knowledge of variability in their presence and activity is required for modeling and prediction of response to future global change.

Stable $\mathrm{N}$ isotope distributions in the ocean are also greatly influenced by $\mathrm{N}$-loss processes (variations in ${ }^{15} \mathrm{~N} /{ }^{14} \mathrm{~N}$ are expressed in the $\delta^{15} \mathrm{~N}$ notation as \%o difference from the ratio for atmospheric $\mathrm{N}_{2}$ ). Dissimilatory $\mathrm{NO}_{3}^{-}$reduction to $\mathrm{NO}_{2}^{-}$ is known to produce both strong $\mathrm{N}$ as well as $\mathrm{O}$ isotopic fractionation (Granger et al., 2008) leaving residual seawater $\mathrm{NO}_{3}^{-}$enriched and the product $\mathrm{NO}_{2}^{-}$depleted in ${ }^{15} \mathrm{~N}$ and ${ }^{18} \mathrm{O}$ (Casciotti and McIlvin, 2007; fractionation factor, $\varepsilon \sim 25 \%$ o). Presumably because ${ }^{15} \mathrm{~N}$-depleted $\mathrm{N}_{2}$ gas is ultimately produced via preferential loss of ${ }^{14} \mathrm{~N}$, this process is responsible for enriching the oceanic fixed-N inventory in ${ }^{15} \mathrm{~N}\left(\delta^{15} \mathrm{~N} \sim 5 \%\right.$ relative to atmospheric $\mathrm{N}_{2}$; Sigman et al., 2009) as compared to sources (e.g. -1 to $-2 \%$ for $\mathrm{N}_{2}$ fixation; Carpenter et al., 1997).

Regionally high $\delta^{15} \mathrm{~N}$ values for residual $\mathrm{NO}_{3}^{-}\left(\delta^{15} \mathrm{NO}_{3}^{-}\right)$ in OMZ's produce a corresponding signal in underlying sediments via upwelling and phytoplankton assimilation and downcore records reveal that OMZ's N-loss has been highly sensitive to past climate change (e.g. Altabet et al., 2002). These isotopic effects have also been used to quantitatively constrain the modern ocean's N-budget. Due to physical transport limitation of substrates into and through sediments, benthic $\mathrm{N}$-loss produces little isotopic fractionation as compared to water column N-loss in OMZ's. This distinction allows isotopic mass balances and the average oceanic $\delta^{15} \mathrm{NO}_{3}^{-}$ to be used to estimate the relative importance of N-loss in sediments vs. the water column, as well as the magnitude of the overall oceanic N sink (Brandes and Devol, 2002). However, such calculations are highly dependent on the choice of effective fractionation factors, which can be influenced by a number of environmental factors (Altabet, 2007) in addition to microbial pathways.

Whereas prior study of OMZ N-loss processes have tacitly assumed a relatively stationary and homogeneous interiorocean environment, the consequences of temporal-spatial variability, particularly with respect to episodic organic matter fluxes, have just begun to be recognized (Thamdrup et al. 2006; Ward et al., 2008, 2009; Dalsgaard et al., 2012). Assumed homogeneity was also once the case for studies of the near-surface ocean with respect to plankton productivity and community ecology. It is now well recognized that physical forcing of temporal-spatial heterogeneity not only produces physical patchiness but also results in higher average oceanic productivity (McGillicuddy and Robinson, 1997; McGillicuddy et al., 1998). This physical forcing and patchiness often occurs in the form and at the scale of mesoscale eddies. Here we show the first evidence for analogous interactions between eddies and OMZ N-loss.

\section{Sampling and analytical methods}

The physical, chemical, and biological dynamics of the Peru OMZ were studied in a series of cruises carried out as part of the German-led Climate - Biogeochemistry Interactions in the Tropical Ocean program (www.sfb754.de) of the German Research Foundation. In January and February of 2009, a total of 121 stations were occupied between $1^{\circ} \mathrm{N}$ and $18^{\circ} \mathrm{S}$ and from the coast out to $85^{\circ} 50^{\prime} \mathrm{W}$, providing detailed spatial coverage of biogeochemical properties relevant to N-loss processes (Fig. 1a). At each station, water samples were collected using 12-1 Niskin bottles on a CTD rosette system equipped with temperature, pressure, conductivity and oxygen sensors. Nutrients and oxygen were determined according to Grasshoff et al. (1999).

The isotopic composition of dissolved $\mathrm{NO}_{3}^{-}$was measured using Cd-reduction to $\mathrm{NO}_{2}^{-}$followed by reaction with azide to produce $\mathrm{N}_{2} \mathrm{O}$ (McIlvin and Altabet, 2005). $\mathrm{NaCl}$ was added to ensure consistent quantitative yield (Ryabenko et al., 2009). Pre-existing $\mathrm{NO}_{2}^{-}$was removed at the time of collection by addition of sulfanilic acid (Ryabenko et al., 2012). For $\mathrm{NO}_{2}^{-}$isotopic analysis, a separate sample set was collected and preserved frozen and only the azide treatment was applied. International references USGS 34, USGS 35, and IAEA N3 were used for calibration. Samples were analyzed in both Germany (GEOMAR) and in the USA (SMAST) using a purge-trap isotope ratio mass spectrometer (PT-IRMS) system. Reproducibility was 0.3 and $0.6 \%$ for $\delta^{15} \mathrm{~N}$ and $\delta^{18} \mathrm{O}$, respectively.

High precision $\mathrm{N}_{2} / \mathrm{Ar}$ for detection of biogenic $\mathrm{N}_{2}$ and $\delta^{15} \mathrm{~N}-\mathrm{N}_{2}$ were determined on septum sealed samples using on-line gas extraction system coupled to a multicollector IRMS. These data were produced by removing $\mathrm{O}_{2}$ in the samples prior to introduction into the mass spectrometer to 

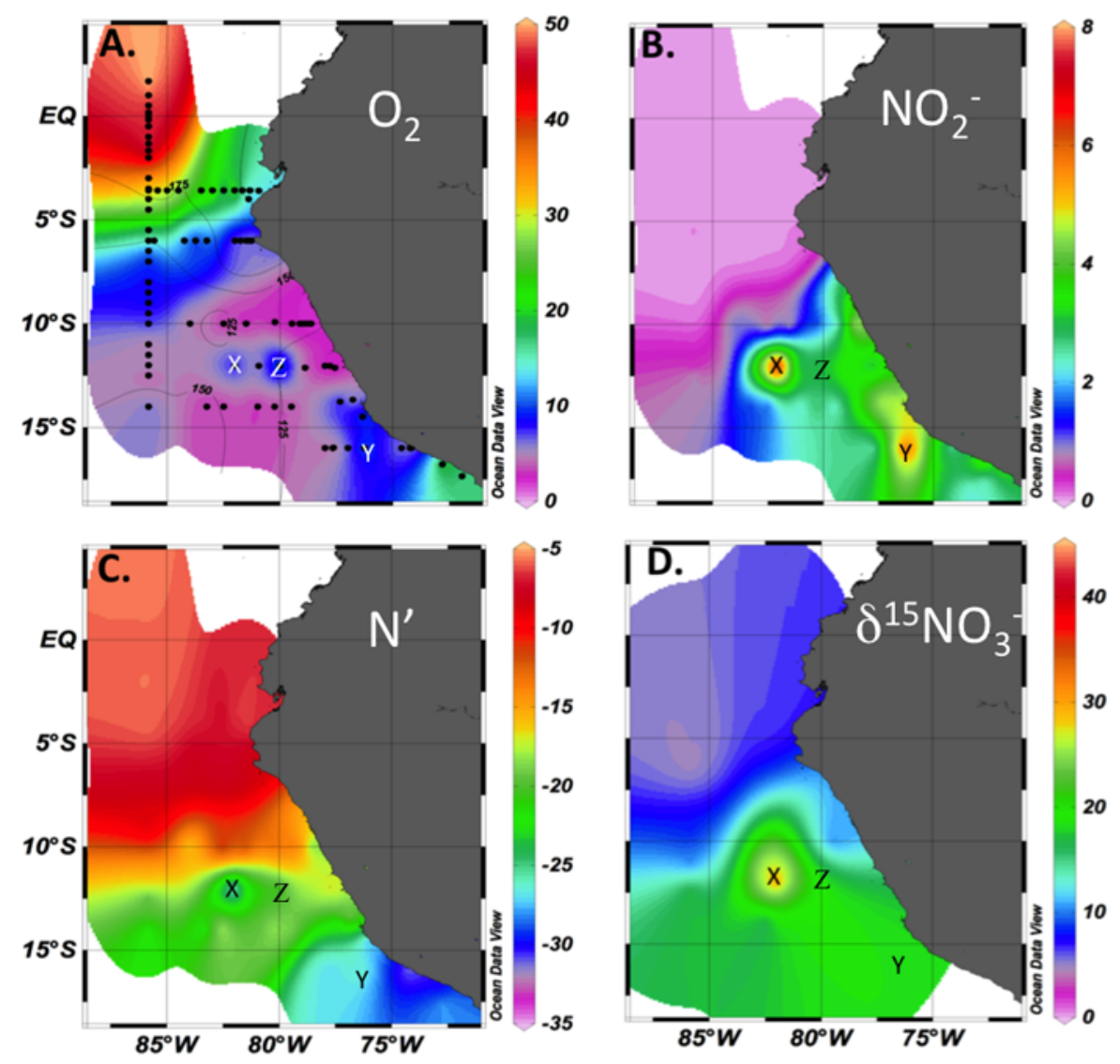

Fig. 1. Biogeochemical maps of the Peru OMZ from a series of stations constituting 6 transects normal and 1 transect parallel to the coast occupied during cruises M77/3 and M77/4 of the German research vessel R/V Meteor in January and February of 2009. Properties are shown along a constant density surface $\left(\sigma_{\theta}=26.3 \mathrm{~kg} \mathrm{~m}^{-3}\right)$ within the upper portion of the OMZ corresponding to a depth range of 100 to $170 \mathrm{~m}$. (A) $\mathrm{O}_{2}$ concentration $\left(\mu \mathrm{mol} \mathrm{kg}{ }^{-1}\right)$, station locations, and depth of the $\sigma_{\theta}=26.3 \mathrm{~kg} \mathrm{~m}^{-3}$ surface. $(\mathbf{B}) \mathrm{NO}_{2}^{-}$concentration $(\mu \mathrm{mol} \mathrm{kg}-1)$. $(\mathbf{C})$ Nitrogen anomaly $\left(\mathrm{N}^{\prime}, \mu \mathrm{mol} \mathrm{kg}{ }^{-1}\right.$ ) calculated as $\left[\mathrm{NO}_{3}^{-}\right]+\left[\mathrm{NO}_{2}^{-}\right]-16 \times\left[\mathrm{PO}_{4}^{-3}\right]$. (D) The $\delta^{15} \mathrm{~N}^{-}$of $\mathrm{NO}_{3}^{-}$. When southward intensification of suboxic conditions reaches $\left[\mathrm{O}_{2}\right]<5 \mu \mathrm{mol} \mathrm{kg}{ }^{-1}$, the onset of $\mathrm{N}$-loss processes is evident. Location of Station 7, a hotspot for N-loss, is marked by an "X". Data smoothing to produce this visualization diminishes somewhat the extrema found at Station 7 (see Fig. 2). A second hotspot (Station 29) was also detected (marked by a "Y"), but is not discussed in the text due to a less comprehensive data set for this site. The position of a more normal comparison station (see Fig. 2) is marked by a "Z".

avoid artifacts associated with varying $\mathrm{N}_{2} / \mathrm{O}_{2}$ (Devol et al., 2006). In terms of calculated biogenic $\mathrm{N}_{2}$, certainty is on the order of $\pm 1 \mu \mathrm{mol} \mathrm{kg}{ }^{-1} \cdot \delta^{15} \mathrm{~N}-\mathrm{N}_{2}$ data were acquired during the same analytical sessions with a certainty of $\pm 0.05 \%$. Publicly available satellite data for sea surface chlorophyll (SSC) are from the NASA Giovanni website (http://gdata1. sci.gsfc.nasa.gov) and sea level anomaly (SLA) are from the AVISO website (http://www.aviso.oceanobs.com).

\section{Results}

\subsection{Properties maps of the Peru OMZ}

For context, relevant biogeochemical properties are mapped along a constant density (isopycnal) surface to highlight the effects of non-conservative, $\mathrm{N}$-cycling processes
(Fig. 1). The chosen isopycnal density corresponding to $\sigma_{\theta}=26.3 \mathrm{~kg} \mathrm{~m}^{-3}$ varied between 100 and $170 \mathrm{~m}$ depth and was located vertically near the top of the $\mathrm{O}_{2}$ minimum layer of the water column. South of 7 to $10^{\circ} \mathrm{S}, \mathrm{O}_{2}$ concentrations on this isopycnal surface were generally low enough to enable N-loss processes $\left(<3 \mu \mathrm{mol} \mathrm{kg}{ }^{-1}\right.$; Fig. 1a) consistent with prior observations (Codispoti and Christensen, 1985). Southward intensification of the OMZ along its northern boundary is associated with the poleward flow of the Peru Undercurrent (PUC) partly sourced in the lower equatorial undercurrent (Strub et al., 1987), comprising both the OMZ's core and the primary source of upwelled waters in this region. Onset of dissimilatory $\mathrm{NO}_{3}^{-}$reduction in the $\mathrm{OMZ}$ is marked by the pronounced appearance of $\mathrm{NO}_{2}^{-}$, which is both an intermediate for HDN and DNRA, as well as a substrate for ANM (Fig. 1b). For most of the open ocean portion of the 
Peru OMZ, maximal $\left[\mathrm{NO}_{2}^{-}\right]$is $<5 \mu \mathrm{mol} \mathrm{kg}{ }^{-1}$. Net $\mathrm{N}$-loss as a consequence of $\mathrm{NO}_{3}^{-}$conversion to $\mathrm{N}_{2}$ gas has been previously estimated using $\mathrm{N}$-deficit calculations based on anomalies in the oxidized forms of $\mathrm{N}$ relative to the Redfield proportionality with $\mathrm{PO}_{4}^{-3}$ (Devol et al., 2006):

$\mathrm{N}^{\prime}=\mathrm{NO}_{3}^{-}+\mathrm{NO}_{2}^{-}-16 \times \mathrm{PO}_{4}^{-3}$

The N-deficit, $\mathrm{N}^{\prime}$, is similar to the $\mathrm{N}^{*}$ formulation (Gruber and Sarmiento, 1997) but without the latter's constant offset (Appendix A). $\mathrm{NH}_{4}^{+}$is not included as its concentration has been observed to be very low to non-detectable throughout much of our study area, particularly seaward of the shelf. South of 7 to $10^{\circ} \mathrm{S}, \mathrm{N}^{\prime}$ decreases from -5 to $-30 \mu \mathrm{mol} / \mathrm{kg}$ along $\sigma_{\theta}=26.3 \mathrm{~kg} \mathrm{~m}^{-3}$ confirming substantial N-loss correlated with the $\mathrm{O}_{2}$ and $\mathrm{NO}_{2}^{-}$observations (Fig. 1c). Consistent with $\mathrm{N}$-loss via dissimilatory $\mathrm{NO}_{3}^{-}$reduction, $\delta^{15} \mathrm{~N}$ values for residual $\mathrm{NO}_{3}^{-}$are inversely correlated with $\mathrm{N}^{\prime}$ (Fig. 1d).

\subsection{An N-loss hotspot}

Our biogeochemical maps reveal one highly anomalous offshore station $\left(12^{\circ} \mathrm{S} 82^{\circ} \mathrm{W}\right.$, Station 7) characterized by extreme values for N-loss indicators with respect to the background geographic gradients. We believe a 2 nd hotspot is evident in these maps (Station 29, $16^{\circ} \mathrm{S} 76^{\circ} 27^{\prime} \mathrm{W}$ ) but is not discussed further due to a less comprehensive dataset available for this site. Station 7 is marked by strongly elevated $\left[\mathrm{NO}_{2}^{-}\right]$of up to $10 \mu \mathrm{mol} \mathrm{kg}{ }^{-1}$, high $\delta^{15} \mathrm{NO}_{3}^{-}$, as well as very negative $\mathrm{N}^{\prime}$ signature (Fig. 2a) in comparison with surrounding stations including adjacent shoreward Station 9 (Figs. 1 and 2). The highest measured values of $\delta^{15} \mathrm{~N}$ and $\delta^{18} \mathrm{O}$ for $\mathrm{OMZ} \mathrm{NO}_{3}^{-}$that we are aware of, are also observed at this station reaching 40 and $34 \%$, respectively (Fig. 2b). In contrast, ocean-wide $\delta^{15} \mathrm{NO}_{3}^{-}$averages are near 5 and $2 \%$, respectively (Sigman et al., 2009). At our other Peru OMZ stations, maximal $\delta^{15} \mathrm{NO}_{3}^{-}$is typically $\sim 15 \%$ and values as high as $24 \%$ o have been reported from other OMZ's (Altabet et al., 1999). Although the extrema are relatively shallow $(100 \mathrm{~m})$, these $\mathrm{N}$-loss indicators at Station 7 extend broadly over the water column down to $400 \mathrm{~m}$ depth, corresponding to the layer of lowest $\mathrm{O}_{2}$ concentration (Figs. 2, 3). Sections for $\mathrm{N}^{\prime}$ and $\left[\mathrm{NO}_{2}^{-}\right]$on a $\mathrm{E}-\mathrm{W}$ transect at $12^{\circ} \mathrm{S}$ also confirm Station 7 to be distinct as compared to neighboring stations, particularly with respect to the greater vertical extent of maxima. In contrast, the adjacent section at $14^{\circ} \mathrm{S}$ shows no evidence for an offshore N-loss hotspot (Fig. 3).

Dissimilatory $\mathrm{NO}_{3}^{-}$reduction to $\mathrm{NO}_{2}^{-}$is known to produce $\mathrm{N}$ and $\mathrm{O}$ isotopic fractionation with a characteristic slope near 1 (Granger et al., 2008). Deviations from this relationship are a common feature of the limited data sets available for OMZ's and have been interpreted as evidence for co-occurrence of other $\mathrm{N}$-transformation processes including $\mathrm{NO}_{2}^{-}$oxidation and contributions from $\mathrm{N}_{2}$ fixation (Casciotti and McIlvin, 2007; Sigman et al., 2005). In contrast, at Station 7 as well as nearby stations with less extreme N-loss indicators (e.g. Station 9), co-variation between $\mathrm{NO}_{3}^{-} \delta^{15} \mathrm{~N}$ and $\delta^{18} \mathrm{O}$ is indistinguishable from a slope of 1 , implying dominance of $\mathrm{NO}_{3}^{-}$reduction both at this site and more regionally (Fig. 2c). A Rayleigh fractionation model (Fig. 2d) can be used to estimate an "apparent" fractionation factor $(\varepsilon)$ for N-loss assuming approximation to a closed system as done in prior studies (e.g. Voss et al., 2001). $\varepsilon$ is found to be lower $(\sim 17 \%$; Fig. 2 d) than previously considered typical for OMZ N-loss for both Stations 7 and 9, consistent with this being typical of the average behavior for the Peru OMZ (Ryabenko et al., 2012), given this method of data treatment.

\subsection{Biogenic $\mathrm{N}_{2}$}

The amount of biogenic $\mathrm{N}_{2}$ production resulting from $\mathrm{N}$-loss processes (HDN or ANM) can be estimated from high precision $\mathrm{N}_{2} / \mathrm{Ar}$ determinations (Chang et al., 2010). Biogenic $\mathrm{N}_{2}$ production increases the measured $\mathrm{N}_{2} / \mathrm{Ar}$ ratio over the value predicted from equilibration with the atmosphere at in situ temperature and salinity. Deviations from equilibrium $\mathrm{N}_{2} / \mathrm{Ar}$ ratios are also known to arise from physical processes such as bubble injection in water mass formation regions. Our data are adjusted as previously described to account for this (Chang et al., 2010), allowing estimation of an "excess" $\mathrm{N}_{2}$ concentration due to biological processes. Biogenic $\mathrm{N}_{2}$ concentrations below the oceanic mixed layer can also be predicted using Richards stoichiometry (Richards, 1965) which takes into account nitrogen originating from the breakdown of $\mathrm{OM}$ that does not appear as $\mathrm{NH}_{4}^{+}$and is assumed to be also converted to $\mathrm{N}_{2}$ (Appendix A):

$\mathrm{N}_{2}$ biogenic $\left(\right.$ as $\mu$ mol kg $\left.{ }^{-1} \mathrm{~N}_{2}\right)=\left(\mathrm{N}_{\text {source waters }}^{\prime}-\mathrm{N}_{\mathrm{OMZ}}^{\prime}\right) \times 0.5$

Measured biogenic $\mathrm{N}_{2}$ concentrations throughout the $\mathrm{OMZ}$ at Station 7 (70 to $400 \mathrm{~m}$ ) closely follows concentrations predicted from the $\mathrm{N}^{\prime}$ data (Fig. 4a) suggesting that $\mathrm{NO}_{3}^{-}$removal is well balanced by biogenic $\mathrm{N}_{2}$ production even for these relatively high OMZ values. However, measured biogenic $\mathrm{N}_{2}$ concentrations in the oxycline of Station 7, above the core of the OMZ (50 to $70 \mathrm{~m}$ ), are twice as high as the values predicted from $\mathrm{N}^{\prime}$ and $>20$ times our analytical uncertainty. Our observations at other "normal" offshore stations, as well as recently published data (Chang et al., 2010), do not show this unusual feature.

The biogenic $\mathrm{N}_{2}$ maximum at 50 to $70 \mathrm{~m}$ at Station 7 is also unique with respect to its isotopic composition. Our method for $\mathrm{N}_{2} /$ Ar determination allows the $\delta^{15} \mathrm{~N}$ of dissolved $\mathrm{N}_{2}$ to be measured at very high precision (better than $\pm 0.05 \%$ o), which provides further information concerning the source of biogenic $\mathrm{N}_{2}$. Such high precision is needed to detect the isotopic ratio of the biogenic $\mathrm{N}_{2}$ above the large background of atmospheric $\mathrm{N}_{2}$. We calculate predicted $\delta^{15} \mathrm{~N}$ $\mathrm{N}_{2}$ anomalies relative to the atmospheric background based on an isotope mass balance with $\mathrm{NO}_{3}^{-}$and $\mathrm{NO}_{2}^{-}$. We assume that the mass-weighted difference between $\delta^{15} \mathrm{~N}$ of source 
A.

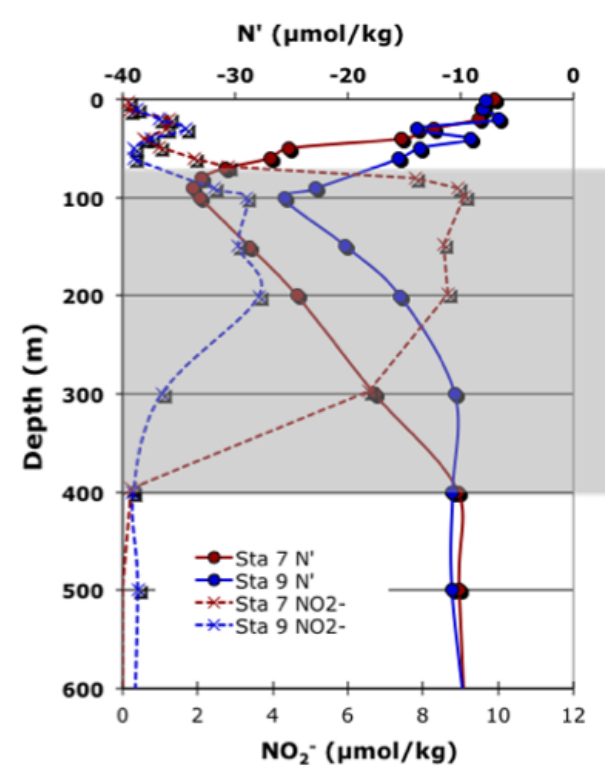

C.

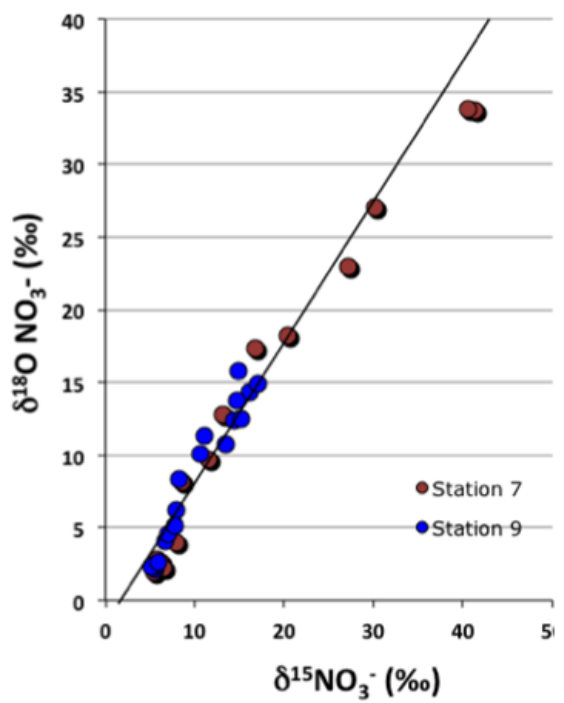

B.

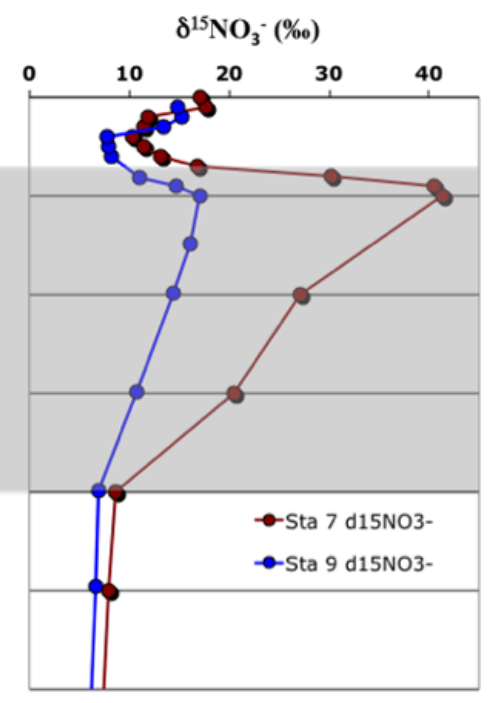

D.

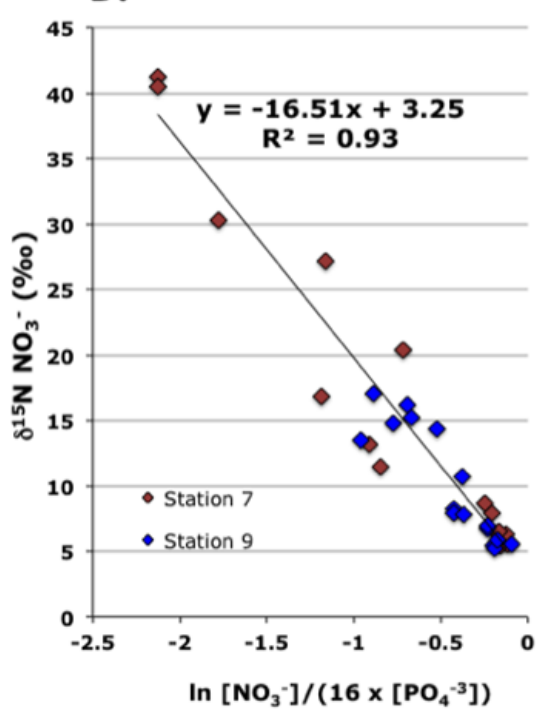

Fig. 2. Depth profiles for N-loss indicators at Station 7 showing extreme values as compared to nearby, shoreward Station 9. OMZ $\left(\mathrm{O}_{2}<3 \mu \mathrm{mol} \mathrm{kg}-1\right)$ indicated as a shaded depth interval (see also Fig. 3). (A) $\mathrm{NO}_{2}^{-}$and $\mathrm{N}$-deficit $\left(\mathrm{N}^{\prime}\right)$ concentration profiles $(\mu \mathrm{mol} \mathrm{kg}-1)$. (B) Profiles for $\delta^{15} \mathrm{NO}_{3}^{-}$(\%o relative to atmospher $\mathrm{N}_{2}$ ). (C) Crossplot of the $\delta^{18} \mathrm{O}$ vs. the $\delta^{15} \mathrm{~N}$ of $\mathrm{NO}_{3}^{-}$. (D) Rayleigh plot of $\delta^{15} \mathrm{NO}_{3}^{-}$vs. the $\ln$ of the residual $\mathrm{NO}_{3}^{-}$fraction assuming the $\mathrm{NO}_{3}^{-}$concentration prior to removal is approximated as $16 \times\left[\mathrm{PO}_{4}^{-3}\right]$. The inverse slope estimates the fractionation effect $(\varepsilon)$ at $\sim 17 \%$.

and $\mathrm{OMZ}$ waters must be reflected in biogenic $\mathrm{N}_{2}$ (Appendix A). As with biogenic $\mathrm{N}_{2}$ concentration, the predicted anomalies in the $\delta^{15} \mathrm{~N}$ of total $\mathrm{N}_{2}$ (atmospheric background plus biogenic) are in agreement with the measured values throughout most of the OMZ (Fig. 4b). Together these data are consistent with a simple mass balance between $\mathrm{NO}_{3}^{-}$removal and biogenic $\mathrm{N}_{2}$ production. However, large discrep- ancies between measured and predicted isotopic ratios are observed within the oxycline, where a $0.25 \%$ o higher than expected signal is observed at the biogenic $\mathrm{N}_{2}$ maximum (Fig. 4b). Whereas the predicted $\delta^{15} \mathrm{~N}$ of the biogenic $\mathrm{N}_{2}$ component alone ranges from -5 to $+3 \%$ (also from $\mathrm{NO}_{3}^{-}$ and $\mathrm{NO}_{2}^{-}$isotope mass balance), these measurements imply that the $\delta^{15} \mathrm{~N}$ of the biogenic $\mathrm{N}_{2}$ at this depth is substantially 

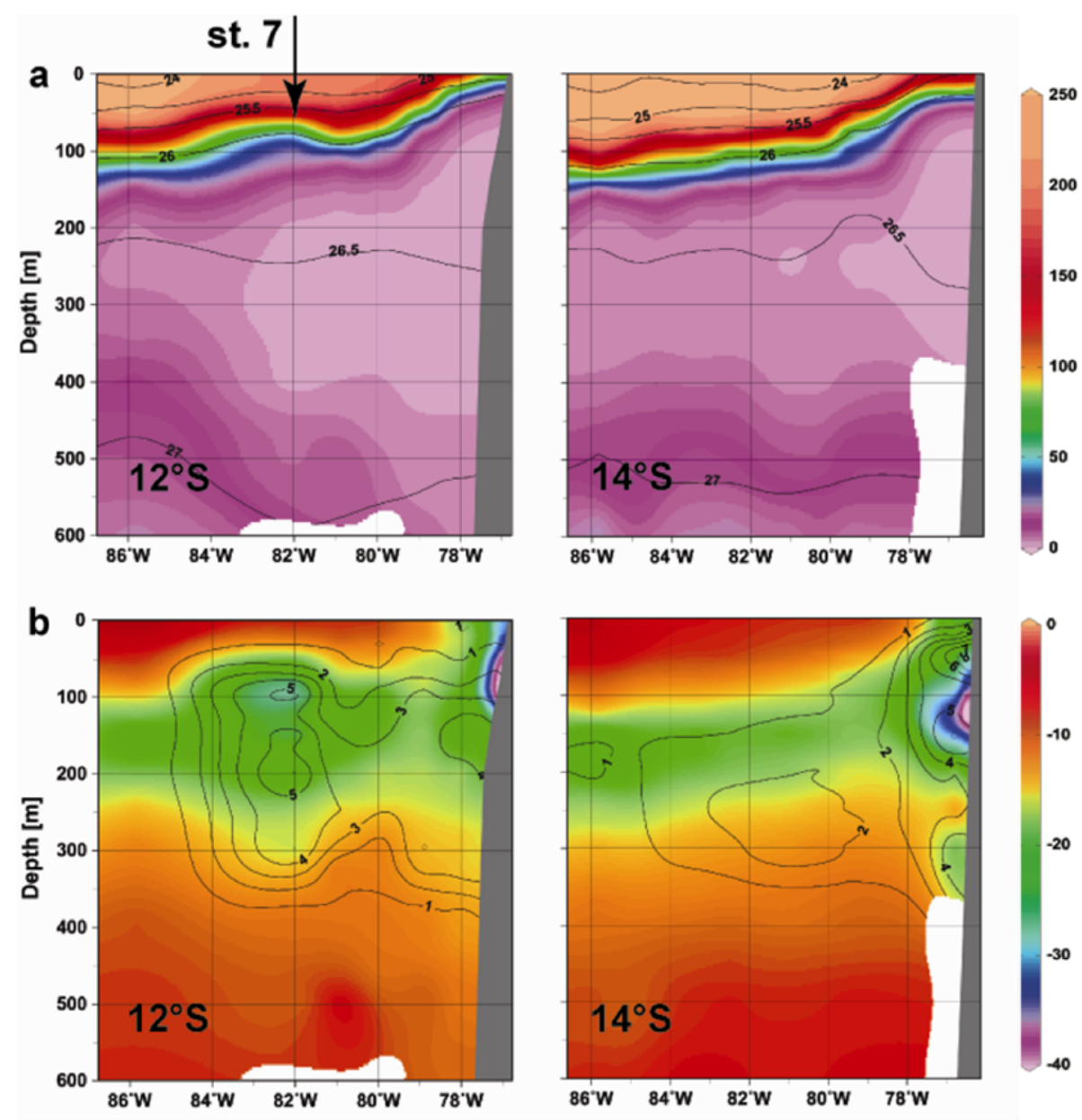

Fig. 3. Property distribution section off the Peru coast. (A) $\mathrm{O}_{2}$ concentration ( $\mu \mathrm{mol} \mathrm{kg}{ }^{-1}$; color shading) and $\sigma_{\theta}$ (contour lines) sections at 12 and $14^{\circ} \mathrm{S}$ latitude (see station positions in Fig. 1). Station 7 is part of the $12^{\circ} \mathrm{S}$ section and its position is marked. (B) Corresponding $\mathrm{N}^{\prime}$ (color shading) and $\mathrm{NO}_{2}^{-}$concentration (contour lines) sections at 12 and $14^{\circ} \mathrm{S}$. Units are in $\mu \mathrm{mol} \mathrm{kg}{ }^{-1}$. Data smoothing to produce this visualization diminishes somewhat the extrema found at Station 7 (see Fig. 2).

higher, $\sim+5 \%$. This implies that the allochthonous biogenic $\mathrm{N}_{2}$ found in the oxycline was produced from $\mathrm{NO}_{3}^{-}$(or $\mathrm{NH}_{4}^{+}$) with little isotope fractionation and is distinct from the apparent autochthonous source within the OMZ below it.

Two separate sets of phenomena thus appear to have contributed to the N-loss hotspot at Station 7. Our biogeochemical and isotopic indicators support the formation of the relatively large amounts of biogenic $\mathrm{N}_{2}$ within the $\mathrm{OMZ}$ at Station 7 through canonical processes (reduction of pre-existing $\mathrm{NO}_{3}^{-}$). However, the biogenic $\mathrm{N}_{2}$ observed within the oxycline appears to have formed rather differently since it (1) is present in oxygenated waters, (2) is found at levels stoichiometrically inconsistent with observed $\mathrm{N}^{\prime}$ and (3) has an isotopic composition that is also inconsistent with production from pre-exiting $\mathrm{NO}_{3}^{-}$. We will discuss below a likely shelf source for this biogenic $\mathrm{N}_{2}$ found above the OMZ.

\subsection{Eddy impacts}

Previously, patches of high $\left[\mathrm{NO}_{2}^{-}\right]$along the Peru margin were found to be associated with seaward current jets (Friederich and Codispoti, 1987). Understanding the N-loss hotspot status of Station 7 therefore likely requires consideration of any synoptic mesoscale variability. As observed from satellite images, both anticyclonic and cyclonic eddies are important and persistent features of the circulation of this coastal upwelling system, as well as of the eastern tropical South Pacific as a whole (Chaigneau et al., 2008). Off Peru, coherent eddies are typically formed along the coast and propagate westward at 3 to $6 \mathrm{~km} \mathrm{~d}^{-1}$ and have a mean eddy lifetime of $\sim 1$ month. Their mean radius is $80 \mathrm{~km}$, increasing equatorward due to the increasing Rossby Radius of Deformation. Eddies are most frequently observed off Chimbote $\left(9^{\circ} \mathrm{S}\right)$ and south of San Juan $\left(15^{\circ} \mathrm{S}\right)$, north and south of Station 7. As detected by satellite sea surface chlorophyll (SSC; phytoplankton concentration) and satellite sea level 


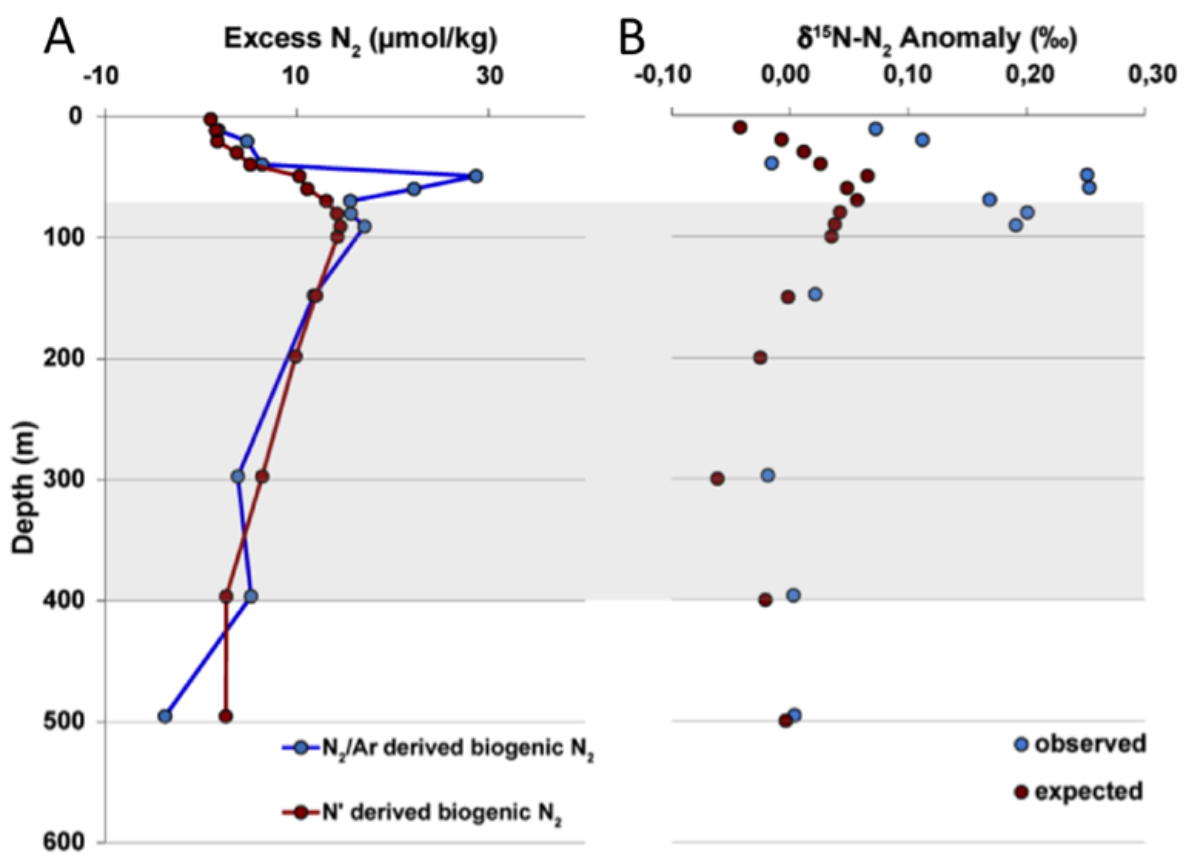

Fig. 4. Biogenic $\mathrm{N}_{2}$ depth profiles at Station 7. (A) Measured and expected excess $\mathrm{N}_{2}$ (biogenic) concentration $\left(\mu \mathrm{mol} \mathrm{kg}^{-1}\right.$ ). (B) The measured and expected $\delta^{15} \mathrm{~N}$ anomaly for $\mathrm{N}_{2}$. OMZ indicated as a shaded depth interval. Expected biogenic $\mathrm{N}_{2}$ is derived from the nitrogen anomaly $\left(\mathrm{N}^{\prime}\right)$ assuming Richards stoichiometry (Richards, 1965) after taking into account $\mathrm{N}^{\prime}$ for water masses upstream of the OMZ (Appendix A). Measured biogenic $\mathrm{N}_{2}$ is calculated from deviations in $\mathrm{N}_{2} / \mathrm{Ar}$ ratio from values expected at saturation with the atmosphere at in situ temperature and salinity and adjusted for physical sources of $\mathrm{N}_{2} / \mathrm{Ar}$ anomaly by comparison with stations outside the OMZ (Chang et al., 2010). The expected $\delta^{15} \mathrm{~N}$ anomaly for $\mathrm{N}_{2}$ is based on isotopic mass balance between the system's source $\mathrm{NO}_{3}^{-}$and $\mathrm{OMZ} \mathrm{NO}_{3}^{-}$and $\mathrm{NO}_{2}^{-}$(Appendix A).

anomaly (SLA; mesoscale circulation), Station 7 was located on the seaward flank of a large eddy trapped near the coast and centered near $11^{\circ} \mathrm{S}$ and $80.5^{\circ} \mathrm{W}$ (Fig. 5). Further evidence of Station 7's having been located within the edge of an anticyclonic eddy is seen in the $\mathrm{O}_{2}$ section at $12^{\circ} \mathrm{S}$, which shows this station to be located at the periphery of a "bowllike" distribution (Fig. 3). The region inshore of Station 7 with deepening oxycline on this section includes Station 9 and corresponds to part of the eddy's interior. Note that Station 7 was occupied on 5 January 2009, whereas the SSC map is an average for the entire month. However, the SLA data represent a 1-day snapshot for 7 January 2009 and the overlay between the current vectors and SSC suggest that the eddy was relatively stationary in this location throughout the observation period. In fact, SSC images for December 2008 and February 2009 also show the eddy to be in the same location.

The SSC imagery reveals low phytoplankton concentrations at the eddy's center and high values around most of its periphery. To the northwest, a high SSC filament appears to have been pulled offshore from the highly productive inshore upwelling region perhaps through interaction between the eddy's circulation and the equatorward mean flow at the surface in this region. Very high inshore productivity is asso- ciated with intense upwelling of nutrient-rich $\left(\mathrm{NO}_{3}^{-}, \mathrm{PO}_{4}^{-3}\right.$, and silicate) waters on the shallow shelf, coupled with $\mathrm{Fe}$ release from the sediment that relieves Fe limitation (Bruland et al., 2005). SLA reflects current structures superimposed on the mean flow. When overlaid on the SSC map, current vectors derived from the satellite SLA data confirm the eddy to be a strong anticyclonic feature as well as the offshore motion of the northwestern SSC filament (Fig. 5). Given the observed eddy size and a swirl velocity of $\sim 20 \mathrm{~km} \mathrm{~d}^{-1}$ estimated from the SLA data and on board ADCP measurements, it took approximately 20 days to transport coastal water to the location of Station 7. Thus there is sufficient time for this and other eddies to impact offshore waters as also shown by the observed offshore flowing SSC filament.

\section{Discussion}

We have identified a "hotspot" for N-loss in the Peru OMZ based on the distribution of $\mathrm{N}^{\prime}, \mathrm{NO}_{2}^{-}$, and $\delta^{15} \mathrm{NO}_{3}^{-}$. However, two separate sets of phenomena appear responsible for the biogenic $\mathrm{N}_{2}$ accumulated within and above the OMZ. Due to volumetric considerations, the biogenic $\mathrm{N}_{2}$ within the OMZ (70 to $400 \mathrm{~m}$ ) is the predominant contributor to the total at Station 7 and its N-loss hotspot status. Mass balance 


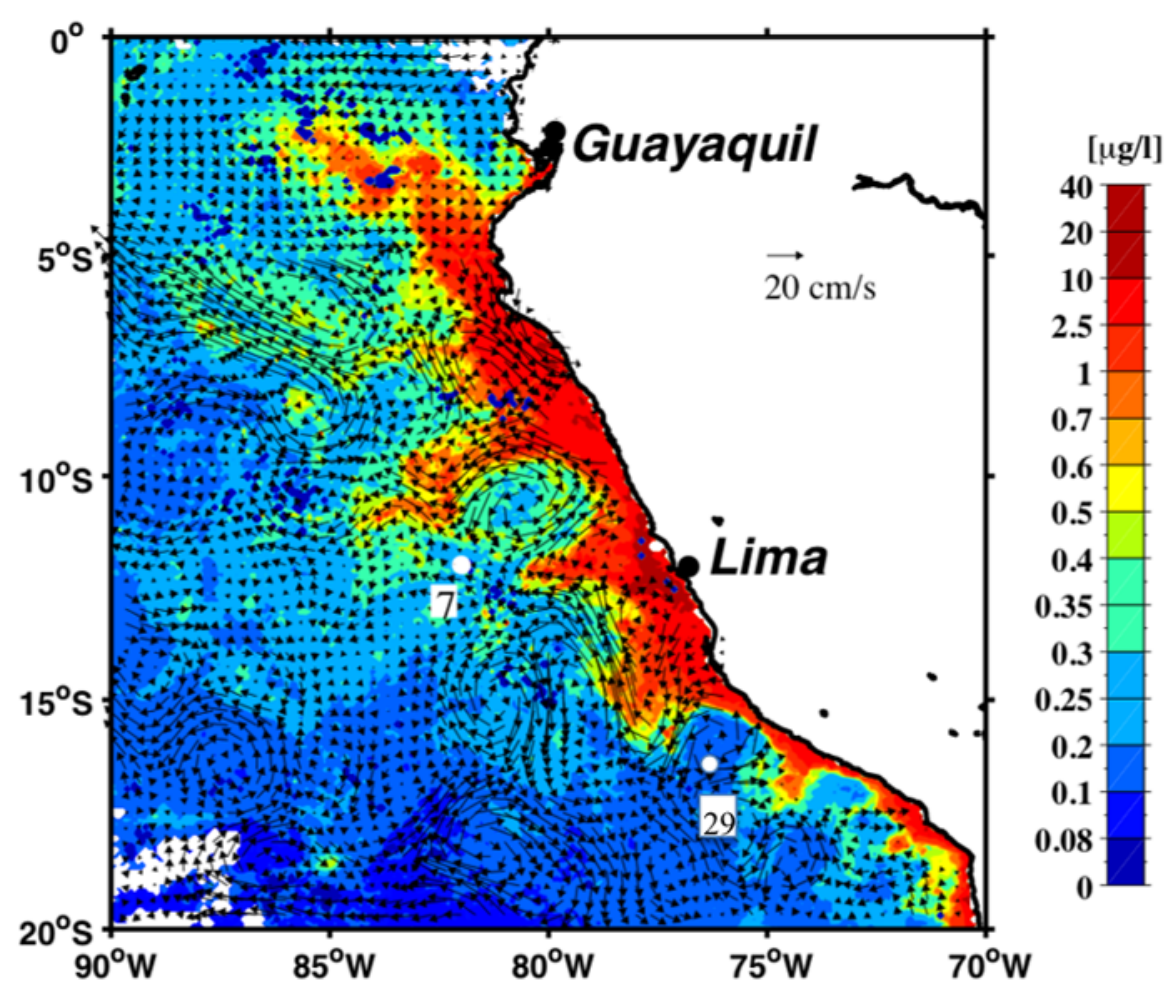

Fig. 5. Satellite observations for the period when Station 7 was occupied (location as indicated). Sea surface chlorophyll (SSC; $\mu \mathrm{g} 1^{-1}$ ) for January 2009 is overlaid by current vectors derived from sea level anomaly (SLA) for 7 January 2009. SSC reflects surface ocean phytoplankton concentration and productivity and was available from the NASA Giovanni website (http://gdata1.sci.gsfc.nasa.gov) as a monthly average. SLA and related current vectors vary in response to barotropic velocity variation from the mean state and is available from the AVISO website (http://www.aviso.oceanobs.com) representing the sea state for a given day.

considerations and isotope analysis furthermore supports its formation by in situ stimulation of the conversion of $\mathrm{NO}_{3}^{-}$ to $\mathrm{N}_{2}$ in the OMZ through a combination of HDN, DNRA, and/or ANM without extraneous $\mathrm{NH}_{4}^{+}$sources for the latter. This stimulation, in turn, appears to be the result of Station 7's being located near or within the seaward edge of a coastally trapped, anticyclonic eddy (Fig. 5). A particular role for eddies in producing N-loss hotspots in association with seaward flowing streamers can account for the uniqueness of this observation (aside from possibly Station 29) as the station grid (Fig. 1) was not designed to resolve synoptic eddy features. It was happenstance that Station 7 was positioned at the seaward flank of a large coastal eddy.

The eddy likely produced the within-OMZ N-loss hotspot through offshore transport of highly productive inshore waters in the form of a high SSC streamer in its northwestern quadrant. We hypothesize that the subsequent downward pulse of $\mathrm{OM}$ in the form of sinking particles stimulates localized $\mathrm{N}$-loss, given the heterotrophic nature of HDN and DNRA processes (Bulow et al., 2010; Thamdrup et al., 2006). While ANM is autotrophic, it is also dependent on $\mathrm{NH}_{4}^{+}$and $\mathrm{NO}_{2}^{-}$supplied by heterotrophic denitrification, DNRA, or other $\mathrm{NO}_{3}^{-}$reducers. Thus dissimilatory
$\mathrm{NO}_{3}^{-}$reduction and concomitant production of biogenic $\mathrm{N}_{2}$ is likely controlled by the OM flux (Ward et al., 2008) which, if episodic, would produce subsurface N-loss hotspots. Although high SSC was not found directly at Station 7, a modest temporal-spatial displacement would be expected between near-surface phytoplankton blooms, bloom collapse, the subsequent downward organic flux, and the appearance of N-loss indicators.

The maxima in biogenic $\mathrm{N}_{2}$ found within the oxycline is, in contrast, likely an advected feature not produced by locally stimulated N-loss in deep offshore waters. Shelf water was clearly advected offshore in the eddy streamer (Fig. 5), suggesting that the biogenic $\mathrm{N}_{2}$ unexpectedly found within the oxycline at 50 to $70 \mathrm{~m}$ had been exported from the inner shelf. These depths are shallow enough for these layers to have been in contact with shelf sediments, a likely direct or indirect source of biogenic $\mathrm{N}_{2}$. By contrast, the larger quantity of biogenic $\mathrm{N}_{2}$ found within the OMZ at Station 7 is too deep to have been advected from the shelf since most of the corresponding isopycnal surfaces intersect the upper slope (Figs. 2, 3). Given that the shallow biogenic $\mathrm{N}_{2}$ peak is almost 3 times higher than expected from coincident $\mathrm{N}^{\prime}$, it is best explained by either biogenic $\mathrm{N}_{2}$ production in shelf 
sediments and/or $\mathrm{NH}_{4}^{+}$release from sediments that is subsequently consumed by ANM in the water column. As such, this high biogenic $\mathrm{N}_{2}$ feature is in itself evidence of direct eddy streamer influence at Station 7 despite a lack of locally high SSC. The high $\delta^{15} \mathrm{~N}$ value for the biogenic $\mathrm{N}_{2}$ maximum is also consistent with a sediment source, where complete removal of fixed-N produces $\mathrm{N}_{2}$ with little or no isotope fractionation (Brandes and Devol, 1997).

An implication of our observations is that coastally trapped eddies can increase the magnitude of regional $\mathrm{N}$ losses through enhanced OM transport to the deep OMZ. Offshore transport of highly productive inshore waters inject large pulses of OM into the deep OMZ that would otherwise be respired in near-surface oxygenated waters or sequestered by inner shelf sediments. By providing fuel for deep-ocean microbial N-loss processes, eddies thereby enhance the OMZ's overall N-loss relative to OM production. Assuming conventional Redfield (1958) and Richards (1965) stoichiometry, photoautotrophic conversion of $30 \mu \mathrm{mol} \mathrm{kg}-1$ of $\mathrm{NO}_{3}^{-}$in the upper $30 \mathrm{~m}$ of upwelled water would produce enough OM to deplete $20 \mu \mathrm{mol} \mathrm{kg}-1$ of $\mathrm{NO}_{3}^{-}$from the upper $250 \mathrm{~m}$ of the offshore OMZ. Eddy lifetime and swirl velocity appear sufficient for this OM to be both produced within the streamers and to sink into the OMZ. When added to the "background" $\mathrm{NO}_{3}^{-}$removal observed throughout the Peru OMZ (Fig. 1), the extreme magnitudes of the N-loss indicators observed at Station 7 are readily explained.

A second implication is that coastal eddies create previously unrecognized spatial as well as temporal variability in deep OMZ biogeochemistry. Hence, apparently inconsistent results among prior studies with respect to the rates of dominant pathways (Thamdrup et al., 2006; Ward et al., 2009; Bulow et al., 2010; Hamersley et al., 2007; Lam et al., 2009) may be explained by station positions that varied relative to the eddy field. Pulses of OM from eddy streamers would also produce temporal succession in the underlying OMZ microbial community. In the oxycline and above, remineralization of $\mathrm{OM}$, production of $\mathrm{NH}_{4}^{+}$, and nitrification (and perhaps $\mathrm{N}_{2} \mathrm{O}$ production) would be transiently enhanced as suggested by earlier observations (Friederich and Codispoti, 1987). Subsequent sinking of OM into the OMZ would stimulate heterotrophic processes supported by $\mathrm{NO}_{3}^{-}$reduction, leading to the observed accumulation of $\mathrm{NO}_{2}^{-}$and $\mathrm{N}$ deficits. Pulses of HDN ("stop and go denitrification") may also lead to $\mathrm{N}_{2} \mathrm{O}$ production (an intermediate in the biochemistry for HDN; Naqvi et al., 2000). $\mathrm{NH}_{4}^{+}$produced directly from $\mathrm{OM}$ and/or DNRA would in turn stimulate ANM. A similar microbial succession in response to OM pulses was also called upon by Dalsgaard et al. (2012) to explain relatively constant rates of ANM but sporadic higher rates of HDN in the Peru N. Chile OMZ. Overall, the Peru OMZ should be viewed as a dynamic system impacted by episodic physical forcing of OM flux that increases $\mathrm{N}$-loss via microbial transformations to biogenic $\mathrm{N}_{2}$. This perspective is critical for the design of future field programs.

Finally, the observed extreme enrichments of $\mathrm{NO}_{3}^{-}{ }^{15} \mathrm{~N}$ and ${ }^{18} \mathrm{O}$ imply that important revisions to global ocean fixed$\mathrm{N}$ and $\mathrm{N}$ isotope budgets may be required. Because sedimentary denitrification produces little $\mathrm{N}$-isotopic fractionation (Brandes and Devol, 1997), the ratio of the average ${ }^{15} \mathrm{~N}$ enrichment in the whole ocean ( $\sim 7 \%$ o compared to sources) to the OMZ denitrification effect $(\sim 25 \%$ o $)$ has been used to estimate the relative contribution of OMZ to oceanic N-loss (Brandes and Devol, 2002). It has been suggested however, that the effective OMZ fractionation effect has been overestimated and consequently its proportion of global marine $\mathrm{N}$-loss has been underestimated (Altabet, 2007). Since the global rate of N-loss in OMZ's is considered to be better constrained than for $\mathrm{N}$-loss in sediments, too high a fractionation factor would also lead to overestimation of total oceanic $\mathrm{N}$-loss and a budget that would imply that $\mathrm{N}$ sinks exceed sources. Here we show an apparent fractionation factor for N-loss lower than canonical for OMZ's (17 vs. $25 \%$ ). Further, the extreme $\mathrm{NO}_{3}^{-}$drawdown observed has important implications for the $\delta^{15} \mathrm{~N}$ of biogenic $\mathrm{N}_{2}$, the term that directly impacts overall the $\mathrm{N}$ isotope budget. Extreme $\mathrm{NO}_{3}^{-}$ removal produces the extreme $\delta^{15} \mathrm{NO}_{3}^{-}$observed at Station 7 and requires, by mass balance, a less isotopically depleted biogenic $\mathrm{N}_{2}$ product. Indeed, the calculated depth integrated average $\delta^{15} \mathrm{~N}$ for biogenic $\mathrm{N}_{2}$ within the OMZ at Station 7 is $\sim-1 \%$ and thus only $6 \%$ less than the oceanic average $\delta^{15} \mathrm{NO}_{3}^{-}$. When applied to global $\mathrm{N}$ isotope budgets, the resulting lower effective fractionation effect for OMZ N-loss also implies that OMZ's account for a larger portion of overall oceanic N-loss than previously thought (Altabet, 2007) as well as an oceanic fixed-N budget closer to balance.

The impact of coastal mesoscale eddies on OMZ N-loss processes reported here is unlikely to be restricted to the waters off Peru, especially as the number of eddies can be greater in the other large OMZ's, off Mexico and in the Arabian Sea (Chelton et al., 2011). However, OMZ's also extend geographically far beyond the region of direct influence of coastal eddies, especially the one off Mexico (Codispoti and Richards, 1976). In oligotrophic open ocean regions, mesoscale eddies in particular are recognized as enhancing the vertical flux of nutrients and primary productivity (McGillicuddy and Robinson, 1997; McGillicuddy et al., 1998). Since most mesoscale eddies have recently been characterized as "non-linear" and capable of advecting water parcels, they have even greater potential for biogeochemical impact on the subsurface ocean (Chelton et al., 2011). Open-ocean eddies may thus produce similar "hotspots" for microbially mediated N-loss even in portions of OMZ's that are distant from productive coastal waters. 


\section{Appendix A}

\section{A1 Use of $\mathrm{N}^{\prime}$ to estimate $\mathrm{NO}_{3}^{-}$ removal and production of biogenic $\mathrm{N} 2$}

Outside of OMZ's, $\mathrm{NO}_{3}^{-}$generally varies in stoichiometric proportion with $\mathrm{PO}_{4}^{-3}$ and $\mathrm{O}_{2}$ as originally observed by Redfield (Redfield, 1958). Negative deviations in $\left[\mathrm{NO}_{3}^{-}\right]$from values expected from these proportions has been termed the $\mathrm{NO}_{3}^{-}$deficit and is used to estimate net removal and production of biogenic $\mathrm{N}_{2}$ in OMZ's (Devol et al., 2006). The commonly used $\mathrm{N}^{*}\left(=\left[\mathrm{NO}_{3}^{-}\right]-16 \times\left[\mathrm{PO}_{4}^{-3}\right]+2.9\right.$; Gruber and Sarmiento, 1997) assumes $\mathrm{NO}_{3}^{-}$as the only form of dissolved inorganic $\mathrm{N}$, uses the Redfield $\mathrm{N}$ : $\mathrm{P}$ ratio, and applies an offset of 2.9 that allows for global average $\mathrm{N}^{*}$ to be 0 . We have used a modification of $\mathrm{N}^{*}\left(\mathrm{~N}^{\prime}=\mathrm{NO}_{3}^{-}+\mathrm{NO}_{2}^{-}-16 \times\right.$ $\mathrm{PO}_{4}^{-3}$ ), which takes into account $\mathrm{NO}_{2}^{-}$, that can be found at significant concentrations in OMZ's, and forgoes the global offset as not being relevant regionally. $\mathrm{N}^{\prime}$ slightly overestimates actual $\mathrm{NO}_{3}^{-}$removal (a more negative $\mathrm{N}^{\prime}$ ) because of $\mathrm{PO}_{4}^{-3}$ release from organic matter breakdown by about $16 \%$ (Devol et al., 2006). Assuming equivalence with $\mathrm{NO}_{3}^{-}$ removal as well as Richards' stoichiometry $\left(1.71: 1 \quad \mathrm{~N}_{2}\right.$; Richards, 1965) and taking into account conversion of organic $\mathrm{N}$ to $\mathrm{N}_{2}$, biogenic $\mathrm{N}_{2}\left(\mathrm{~N}_{2}\right.$ biogenic) can be calculated as:

$\mathrm{N}_{2 \text { biogenic }}\left(\right.$ as $\mu$ molN $\left.N_{2}\right)=\left(\mathrm{N}_{\text {source }}^{\prime}-\mathrm{N}_{\mathrm{OMZ}}^{\prime}\right) \times 0.86 / 1.71$ (A1)

$\mathrm{N}_{2 \text { biogenic }} \sim\left(\mathrm{N}_{\text {source }}^{\prime}-\mathrm{N}_{\mathrm{OMZ}}^{\prime}\right) \times 0.5$

Because the corrections for $\mathrm{PO}_{4}^{-3}$ production and $\mathrm{N}_{2}$ produced from organic N-breakdown assume the same elemental stoichiometry for organic matter, they effectively cancel each other.

The $\mathrm{N}_{\text {source }}^{\prime}$ term accounts for source waters not necessarily having zero $\mathrm{N}$ anomaly. It was measured at stations upstream from the OMZ on isopycnal surfaces corresponding to those bounding the Peru OMZ and is about $-5 \mu \mathrm{mol} \mathrm{kg}{ }^{-1}$ in this system. Figure 3 a compares biogenic $\mathrm{N}_{2}$ calculated in this fashion $\left(\mathrm{N}^{\prime}\right.$ derived) with measured values (from $\mathrm{N}_{2} / \mathrm{Ar}$ ).

\section{A2 Anomaly in the $\delta^{15} \mathrm{~N}$ of $\mathrm{N}_{2}$}

The $\delta^{15} \mathrm{~N}-\mathrm{N}_{2}$ anomaly reported is the difference between the measured value and the value expected at atmospheric equilibrium at in situ temperature and salinity (between 0.6 and $0.8 \% o$ ). For the measured anomaly, the difference between measured $\delta^{15} \mathrm{~N}-\mathrm{N}_{2}$ and the equilibrium value is reported (Fig. 4b). For the expected anomaly, the $\delta^{15} \mathrm{~N}$ of biogenic $\mathrm{N}_{2}$ is first calculated from isotope mass balance between source $\mathrm{NO}_{3}^{-}$and $\mathrm{OMZ} \mathrm{NO}-\mathrm{NO}_{3}^{-}$and $\mathrm{NO}_{2}^{-}$assuming dif- ferences are accounted for by production of biogenic $\mathrm{N}_{2}$ :

$$
\begin{aligned}
& \delta^{15} \mathrm{~N}-\mathrm{N}_{2} \text { biogenic }=\left(\delta^{15} \mathrm{~N}-\mathrm{NO}_{3 \text { source }}^{-} \times\left[\mathrm{NO}_{3}^{-}\right]_{\text {source }}-\left[\mathrm{NO}_{3 \mathrm{OMZ}}^{-}\right]\right. \\
& \left.\times \delta^{15} \mathrm{~N}-\mathrm{NO}_{3} \mathrm{OMZ}^{-}-\left[\mathrm{NO}_{2}^{-}\right]_{\mathrm{OMZ}} \times \delta^{15} \mathrm{~N}-\mathrm{NO}_{2}^{-} \mathrm{OMZ}\right) /\left[\mathrm{N}_{2} \text { biogenic }\right] \\
& {\left[\mathrm{NO}_{3}^{-}\right]_{\text {source }}=16 \times \mathrm{PO}_{4}^{-3} \mathrm{OMZ}+\mathrm{N}_{\text {source }}^{\prime}}
\end{aligned}
$$

As for $\mathrm{N}_{\text {source }}^{\prime}, \delta^{15}{\mathrm{~N}-\mathrm{NO}_{3}^{-}}_{\text {source }}$ is measured at stations upstream of the Peru OMZ and is about 7\%o. Not included is the isotopic signal from the small amount of biogenic $\mathrm{N}_{2}$ produced from organic $\mathrm{N}$, which would be expected to produce a modest increase in its $\delta^{15} \mathrm{~N}$ value in this system.

The expected $\delta^{15} \mathrm{~N}-\mathrm{N}_{2}$ anomaly is calculated by addition of the biogenic $\mathrm{N}_{2}$ signal with the background $\mathrm{N}_{2}$ of atmospheric origin $\left(\mathrm{N}_{2}\right.$ atm; calculated assuming equilibrium at in situ temperature and salinity) with zero $\delta^{15} \mathrm{~N}$ anomaly;

$$
\begin{aligned}
& \delta^{15} \mathrm{~N}-\mathrm{N}_{2} \text { anomaly }=\left(\left[\mathrm{N}_{2} \text { atm }\right] \times \delta^{15} \mathrm{~N}-\mathrm{N}_{2} \text { atm }+\left[\mathrm{N}_{2} \text { biogenic }\right]\right. \\
& \left.\times \delta^{15} \mathrm{~N}-\mathrm{N}_{2} \text { biogenic }\right) /\left(\left[\mathrm{N}_{2 \mathrm{~atm}}\right]+\left[\mathrm{N}_{2} \text { biogenic }\right]\right)
\end{aligned}
$$

Acknowledgements. Enrique Montes aided in sample collection and Jen Larkum and Laura Bristow provided critical technical assistance. Funding to MAA was provided by the US National Science Foundation. Funding to ER, LS, DW, MF, PG and GL was provided by the Deutsche Forschungsgemeinschaft-supported project SFB-754 (www.sfb754.de). The R/V Meteor M77/3 and M77/4 Pacific cruises were granted by the DFG and the crews and captain of $\mathrm{R} / \mathrm{V}$ Meteor are thanked for their help during cruises $\mathrm{M} 77 / 3$ and $\mathrm{M} 77 / 4$.

Edited by: B. Dewitte

\section{References}

Altabet, M. A.: Constraints on oceanic $\mathrm{N}$ balance/imbalance from sedimentary ${ }^{15} \mathrm{~N}$ records, Biogeosciences, 4, 75-86, doi:10.5194/bg-4-75-2007, 2007.

Altabet, M. A., Murray, D. W., and Prell, W. L.: Climatically linked oscillations in Arabian Sea denitrification over the past 1 m.y.: Implications for the marine N cycle, Paleoceanography, 14, 732743, doi:10.1029/1999PA900035, 1999.

Altabet, M. A., Higginson, M. J., and Murray, D. W.: The effect of millennial-scale changes in Arabian Sea denitrification on atmospheric $\mathrm{CO}_{2}$, Nature, 415, 159-162, doi:10.1038/415159a, 2002.

Brandes, J. A. and Devol, A. H.: Isotopic fractionation of oxygen and nitrogen in coastal marine sediments, Geochim. Cosmochim. Ac., 61, 1793-1801, doi:10.1016/S0016-7037(97)00041-0, 1997.

Brandes, J. A. and Devol, A. H.: A global marine-fixed nitrogen isotopic budget: Implications for Holocene nitrogen cycling, Global Biogeochem. Cy., 16, 1120-1134, doi:10.1029/2001GB001856, 2002.

Bruland, K. W., Rue, E. L., Smith, G. J., and DiTullio, G. R.: Iron, macronutrients and diatom blooms in the Peru upwelling regime: brown and blue waters of Peru, Mar. Chem., 93, 81-103, doi:10.1016/j.marchem.2004.06.011, 2005. 
Bulow, S. E., Rich, J. J., Naik, H. S., Pratihary, A. K., and Ward, B. B.: Denitrification exceeds anammox as a nitrogen loss pathway in the Arabian Sea oxygen minimum zone, Deep-Sea Res. Pt. 1, 57, 384-393, doi:10.1016/j.dsr.2009.10.014, 2010.

Carpenter, E. J., Harvey, H. R., Fry, B., and Capone, D. G.: Biogeochemical tracers of the marine cyanobacterium Trichodesmium, Deep-Sea Res. Pt. 1, 44, 27-38, doi:10.1016/S09670637(96)00091-X, 1997.

Casciotti, K. L. and McIlvin, M. R.: Isotopic analyses of nitrate and nitrite from reference mixtures and application to Eastern Tropical North Pacific waters, Mar. Chem., 107, 184-201, doi:10.1016/j.marchem.2007.06.021, 2007.

Chaigneau, A., Gizolme, A., and Grados, C.: Mesoscale eddies off Peru in altimeter records: Identification algorithms and eddy spatio-temporal patterns, Prog. Oceanogr., 79, 106-119, doi:10.1016/j.pocean.2008.10.013, 2008.

Chang, B. X., Devol, A. H., and Emerson, S. R.: Denitrification and the nitrogen gas excess in the eastern tropical South $\mathrm{Pa}-$ cific oxygen deficient zone, Deep-Sea Res. Pt. 1, 57, 1092-1101, doi:10.1016/j.dsr.2010.05.009, 2010.

Chelton, D. B., Schlax, M. G., and Samelson, R. M.: Global observations of nonlinear mesoscale eddies, Prog. Oceanogr., 91, 167-216, doi:10.1016/j.pocean.2011.01.002, 2011.

Codispoti, L. A.: An oceanic fixed nitrogen sink exceeding $400 \mathrm{Tg}$ $\mathrm{N} \mathrm{a}^{-1}$ vs. the concept of homeostasis in the fixed-nitrogen inventory, Biogeosciences, 4, 233-253, doi:10.5194/bg-4-233-2007, 2007.

Codispoti, L. A. and Christensen, J. P.: Nitrification, denitrification and nitrous-oxide cycling in the eastern tropical SouthPacific Ocean, Mar. Chemi., 16, 277-300, doi:10.1016/03044203(85)90051-9, 1985

Codispoti, L. A. and Richards, F. A.: An analysis of the horizontal regime of denitrification in the eastern tropical North Pacific, Limnol. Oceanogr., 21, 379-388, 1976.

Dalsgaard, T., Thamdrup, B., Farías, L., and Peter Revsbech, N.: Anammox and denitrification in the oxygen minimum zone of the eastern South Pacific, Limnol. Oceanogr., 57, 1331-1346, doi:10.4319/lo.2012.57.5.1331, 2012.

Devol, A. H., Uhlenhopp, A. G., Naqvi, S. W. A., Brandes, J. A., Jayakumar, D. A., Naik, H., Gaurin, S., Codispoti, L. A., and Yoshinari, T.: Denitrification rates and excess nitrogen gas concentrations in the Arabian Sea oxygen deficient zone, Deep-Sea Res. Pt. 1, 53, 1533-1547, doi:10.1016/j.dsr.2006.07.005, 2006.

Friederich, G. E. and Codispoti, L. A.: An analysis of continuous vertical nutrient profiles taken during a cold-anomaly off Peru, Deep-Sea Res. Pt. 1, 34, 1049-1065, doi:10.1016/01980149(87)90052-5, 1987.

Granger, J., Sigman, D. M., Lehmann, M. F., and Tortell, P. D.: Nitrogen and oxygen isotope fractionation during dissimilatory nitrate reduction by denitrifying bacteria, Limnol. Oceanogr., 53, 2533-2545, doi:10.4319/lo.2008.53.6.2533, 2008.

Grasshoff, K., Kremling, K., and Ehrhardt, M.: Methods of seawater Analysis - Third Edition, completely revised and extended version, Seawater Analysis Wiley-VCH, 600pp., doi:10.1002/9783527613984, 1999.

Gruber, N.: The marine nitrogen cycle: Overview and challanges, in: Nitrogen in Marine Environment, edited by: Capone, D. G., Bronk, D. A., Mulholland, M. R., and Carpenter, E. J., Elsevier Inc., 1-51, 2008.
Gruber, N. and Sarmiento, J. L.: Global patterns of marine nitrogen fixation and denitrification, Global Biogeochem. Cy., 11, 235266, doi:10.1029/97GB00077, 1997.

Hamersley, M. R., Lavik, G., Woebken, D., Rattray, J. E., Lam, P., Hopmans, E. C., Damste, J. S. S., Kruger, S., Graco, M., Gutierrez, D., and Kuypers, M. M. M.: Anaerobic ammonium oxidation in the Peruvian oxygen minimum zone, Limnol. Oceanogr., 52, 923-933, doi:10.4319/1o.2007.52.3.0923, 2007.

Kalvelage, T., Jensen, M. M., Contreras, S., Revsbech, N. P., Lam, P., Günter, M., LaRoche, J., Lavik, G., and Kuypers, M. M. M.: Oxygen sensitivity of anammox and coupled N-cycle processes in oxygen minimum zones, PLoS One, 6, e29299, doi:10.1371/journal.pone.0029299, 2011.

Kuypers, M. M. M., Sliekers, A. O., Lavik, G., Schmid, M., Jorgensen, B. B., Kuenen, J. G., Damste, J. S. S., Strous, M., and Jetten, M. S. M.: Anaerobic ammonium oxidation by anammox bacteria in the Black Sea, Nature, 422, 608-611, doi:10.1038/nature01472, 2003.

Lam, P., Lavik, G., Jensen, M. M., van de Vossenberg, J., Schmid, M., Woebken, D., Dimitri, G., Amann, R., Jetten, M. S. M., and Kuypers, M. M. M.: Revising the nitrogen cycle in the Peruvian oxygen minimum zone, P. Acad. Sci. USA, 106, 4752-4757, doi:10.1073/pnas.0812444106, 2009.

McGillicuddy, D. J. and Robinson, A. R.: Eddy-induced nutrient supply and new production in the Sargasso Sea, Deep-Sea Res. Pt. 1, 44, 1427-1450, doi:10.1016/S0967-0637(97)00024$1,1997$.

McGillicuddy, D. J., Robinson, A. R., Siegel, D. A., Jannasch, H. W., Johnson, R., Dickeys, T., McNeil, J., Michaels, A. F., and Knap, A. H.: Influence of mesoscale eddies on new production in the Sargasso Sea, Nature, 394, 263-266, doi:10.1038/28367, 1998.

McIlvin, M. R. and Altabet, M. A.: Chemical conversion of nitrate and nitrite to nitrous oxide for nitrogen and oxygen isotopic analysis in freshwater and seawater, Anal. Chem., 77, 5589-5595, doi:10.1021/ac050528s, 2005.

Naqvi, S. W. A., Jayakumar, D. A., Narvekar, P. V., Naik, H., Sarma, V., D'Souza, W., Joseph, S., and George, M. D.: Increased marine production of $\mathrm{N}_{2} \mathrm{O}$ due to intensifying anoxia on the Indian continental shelf, Nature, 408, 346-349, doi:10.1038/35042551, 2000.

Redfield, A. C.: The biological control of chemical factors in the environment, Am. Sci., 46, 205-221, 1958.

Richards, F. A.: Anoxic basins and fjords, in: Chemical Oceanography, edited by: Riley, J. P. and Skirrow, G., Academic Press, London, 611-643, 1965.

Ryabenko, E., Altabet, M. A., and Wallace, D. W. R.: Effect of chloride on the chemical conversion of nitrate to nitrous oxide for $\delta^{15} \mathrm{~N}$ analysis, Limnol. Oceanogr. Methods, 7, 545-552, 2009.

Ryabenko, E., Kock, A., Bange, H. W., Altabet, M. A., and Wallace, D. W. R.: Contrasting biogeochemistry of nitrogen in the Atlantic and Pacific oxygen minimum zones, Biogeosciences 9, 203-215, 10.5194/bg-9-203-2012, 2012.

Sigman, D. M., Granger, J., DiFiore, P. J., Lehmann, M. M., Ho, R., Cane, G., and van Geen, A.: Coupled nitrogen and oxygen isotope measurements of nitrate along the eastern North Pacific margin, Global Biogeochem. Cy., 19, GB4022, doi:10.1029/2005GB002458, 2005. 
Sigman, D. M., DiFiore, P. J., Hain, M. P., Deutsch, C., Wang, Y., Karl, D. M., Knapp, A. N., Lehmann, M. F., and Pantoja, S.: The dual isotopes of deep nitrate as a constraint on the cycle and budget of oceanic fixed nitrogen, Deep-Sea Res. Pt. 1, 56, 14191439, doi:10.1016/j.dsr.2009.04.007, 2009.

Stramma, L., Johnson, G. C., Sprintall, J., and Mohrholz, V.: Expanding oxygen-minimum zones in the tropical oceans, Science, 320, 655-658, doi:10.1126/science.1153847, 2008

Stramma, L., Visbeck, M., Brandt, P., Tanhua, T., and Wallace, D.: Deoxygenation in the oxygen minimum zone of the eastern tropical North Atlantic, Geophys. Res. Lett., 36, L20607, doi:10.1029/2009g1039593, 2009.

Strub, P. T., Allen, J. S., Huyer, A., and Smith, G. J.: Seasonal cycles of currents, temperatures, winds, and sea level over the northeast Pacific continental shelf: $35^{\circ}$ to $48^{\circ}$ N, J. Geophys. Res., 92, 1507-1526, doi:10.1029/JC092iC02p01507, 1987.
Thamdrup, B., Dalsgaard, T., Jensen, M. M., Ulloa, O., Farias, L., and Escribano, R.: Anaerobic ammonium oxidation in the oxygen-deficient waters off northern Chile, Limnol. Oceanogr., 51, 2145-2156, doi:10.4319/lo.2006.51.5.2145, 2006.

Voss, M. and Montoya, J. P.: Nitrogen cycle. Oceans apart, Nature, 461, 49-50, doi:10.1038/461049a, 2009.

Voss, M., Dippner, J. W., and Montoya, J. P.: Nitrogen isotope patterns in the oxygen-deficient waters of the Eastern Tropical North Pacific Ocean, Deep-Sea Res. Pt. 1, 48, 1905-1921, doi:10.1016/S0967-0637(00)00110-2, 2001.

Ward, B. B., Devol, A. H., Rich, J. J., Chang, B. X., Bulow, S. E., Naik, H., Pratihary, A., and Jayakumar, A.: Denitrification as the dominant nitrogen loss process in the Arabian Sea, Nature, 461, 78-81, doi:10.1038/nature08276, 2009.

Ward, B. B., Tuit, C. B., Jayakumar, A., Rich, J. J., Moffett, J., and Naqvi, S. W. A.: Organic carbon, and not copper, controls denitrification in oxygen minimum zones of the ocean, Deep-Sea Res. Pt. 1, 55, 1672-1683, 2008. 